\title{
Evidence of androgen action in endometrial and ovarian cancers
}

Douglas A Gibson, Ioannis Simitsidellis, Frances Collins and Philippa T K Saunders

MRC Centre for Reproductive Health, The University of Edinburgh, The Queen's Medical Research Institute, 47 Little France Crescent, Edinburgh EH16 4TJ, UK
Correspondence should be addressed to P T K Saunders Email p.saunders@ed.ac.uk

\begin{abstract}
Endometrial cancer (EC) and ovarian cancer are common gynaecological malignancies. The impact of androgen action in these cancers is poorly understood; however, there is emerging evidence to suggest that targeting androgen signalling may be of therapeutic benefit. Epidemiological evidence suggests that there is an increased risk of EC associated with exposure to elevated levels of androgens, and genetic variants in genes related to both androgen biosynthesis and action are associated with an increased risk of both EC and ovarian cancer. Androgen receptors (ARs) may be a potential therapeutic target in EC due to reported anti-proliferative activities of androgens. By contrast, androgens may promote growth of some ovarian cancers and anti-androgen therapy has been proposed. Introduction of new therapies targeting ARs expressed in EC or ovarian cancer will require a much greater understanding of the impacts of cell context-specific AR-dependent signalling and how ARs can crosstalk with other steroid receptors during progression of disease. This review considers the evidence that androgens may be important in the aetiology of EC and ovarian cancer with discussion of evidence for androgen action in normal and malignant endometrial and ovarian tissue.
\end{abstract}

\author{
Key Words \\ - androgen \\ - androgen receptor \\ - carcinoma \\ - endometrium \\ - ovary
}

\section{Introduction}

Endometrial cancer (EC) and ovarian cancer are common gynaecological malignancies; however, the impact of androgen action in these cancers is poorly understood. Epidemiological evidence suggests that androgens may be important in the aetiologies of EC and ovarian cancer. Androgen receptor (AR) expression has been described in these malignancies and androgen action has been proposed as a potential therapeutic target. Evidence from cell and animal studies suggests that androgens may have anti-proliferative actions in EC. By contrast, the impact of androgens in ovarian cancer is debated, but some studies suggest that androgens may stimulate ovarian epithelial cell proliferation.

In both normal and malignant tissues, androgen action in the female reproductive system requires a complex convergence of sex steroid biosynthesis, local metabolism and receptor activation. Alterations in any of these elements could have an impact on risk or progression of malignancy. This review appraises the evidence that androgens may be important in the aetiology of EC and ovarian cancer with discussion of disease mechanisms and treatment options.

\section{Epidemiology of EC and ovarian cancer and risks associated with androgen exposure}

\section{Endometrial cancer}

EC is the most common gynaecological cancer and the fourth most common cancer in women in the UK

Published by Bioscientifica Ltd.

This paper is one of 12 papers that form part of a thematic review section on

Androgens and the AR in Breastand Brostate Cancer. The Guest.Editors for this secțion : $55: 14 \mathrm{AM}$

were Wayne Tilley and Frank Claessens. 
(http://www.cancerresearchuk.org). Clinically, ECs are graded according to the FIGO system (revised in 2009 (Lewin 2011)) and have classically been divided into two subtypes: oestrogen-dependent type I and the less common, but clinically more aggressive, oestrogenindependent type II (Emons et al. 2000). Approximately $95 \%$ of endometrial tumours are adenocarcinomas arising due to malignant transformation of the endometrial glandular epithelium (http://www.cancerresearchuk.org). An integrated molecular classification of ECs was recently described combining data from genomic, transcriptomic and proteomic analyses of over 370 ECs leading to further classification of EC subtypes (The Cancer Genome Research Network, Kandoth et al. (2013)). Utilising arraybased and sequencing technologies, ECs were classified into four major groups: i) ultramutated cancers with DNA polymerase epsilon (POLE) mutations (7\%), ii) hypermutated cancers due to DNA mismatch repair and associated microsatellite instabilities (28\%), iii) ECs with low mutation rate and a low frequency of DNA copy-number alterations (CNA, 39\%) and iv) ECs with low mutation rate but high-frequency DNA CNA (26\%). The cancers in the first three groups were almost all endometrioid carcinomas (type I). The fourth group included uterine serous carcinomas and serous-like or serous-related carcinomas thought not to be related to oestrogen exposure or obesity (type II). Although type II ECs are classified as oestrogenindependent, new evidence suggests that both types I and II ECs share many common risk factors, including age at menarche, parity and contraceptive use which may indicate that changes in steroid exposure has an impact on the risk of developing either type I or II EC (Setiawan et al. 2013). Using data collected in the European Prospective Investigation into Cancer and Nutrition (EPIC) study, factor analysis of 233 cases of EC with 446 matched controls identified three factors associated with increased post-menopausal EC risk: 'insulin resistance', 'steroids' and 'inflammation' (Dossus et al. 2013).

The greatest incidence of EC occurs between the ages of 50 and 65 years with peak incidence occurring after menopause (Purdie \& Green 2001). Established risk factors for developing EC are associated with increased exposure to oestrogens throughout the reproductive lifespan such as nulliparity, early menarche and late menopause (Purdie \& Green 2001). Risk is also associated with exposure to selective oestrogen receptor modulators (SERMs) such as tamoxifen administered as part of treatment for breast cancer (Bergman et al. 2000). Incidence of EC increased in the 1970s as a result of oestrogen-only hormone replacement therapy (HRT) use; however, these rates were reduced following the inclusion of progestins in HRT formulations that significantly decrease risk of EC due to the antiproliferative effects of progestins on the endometrium (Beral et al. 2005). Consistent with the anti-proliferative effect of progestins, use of the combined oral contraceptive pill is considered as protective against EC risk (Emons et al. 2000). While the role of progestins and 'unopposed oestrogen' exposure as a determinant of EC risk are well established, the effect of androgen action and exposure on EC risk is less well defined.

In a further analysis of data from the EPIC study, pre-diagnostic concentrations of endogenous hormones including testosterone, androstenedione (A4) and DHEAS were measured in pre- and post-menopausal women. Elevated circulating levels of free testosterone positively correlated with EC risk, but A4 and DHEAS were not associated with increased risk (Allen et al. 2008). The Million Women Study identified that BMI was a major modifiable risk factor and that as many as half of the EC cases in post-menopausal women could be attributed to being obese or overweight (Reeves et al. 2007). Furthermore, an analysis of EC cases in European women estimated that obesity accounted for 39\% of cases (Bergstrom et al. 2001), an association usually attributed to excess exposure to oestrogens as adipose tissue is the primary site of oestrogen production in post-menopausal women (Simpson et al. 1997). Interestingly, a study from the 1980s by Samojlik et al. (1984) examined androgen production in morbidly obese, non-hirsute, normally menstruating women and found that testosterone and dihydrotestosterone (DHT) production rates were elevated twofold compared with controls, but that this increased androgen production was offset by enhanced metabolic clearance. Despite the enhanced clearance described by the authors, the enhanced serum concentrations of androgens suggest that obesity may be a hyperandrogenic state. Consistent with this, recent analyses in the EPIC study demonstrated that concentrations of free testosterone were positively correlated with BMI (Allen et al. 2008). Furthermore, free testosterone and DHEAS are reported to correlate positively with abdominal fat accumulation in post-menopausal women (Cao et al. 2013).

Polycystic ovarian syndrome (PCOS) is an endocrine disorder affecting women of reproductive age and is associated with menstrual cycle disturbances, hyperandrogenism and infertility (Hart et al. 2004). Exposure to elevated androgens during the reproductive years in women with PCOS may adversely impact on endometrial function. PCOS has long been associated with an increased risk of EC and prolonged periods of anovulation may

Published by Bioscientifica Ltd. 
increase exposure to both androgens and oestrogens. PCOS and EC share many of the same risk factors and a recent population-based case-control study in Australia found that women with PCOS have a fourfold increased risk of EC compared with women without PCOS (Fearnley et al. 2010). This risk was elevated for type I cancers and had a greater association with symptoms of androgen excess such as hirsutism (OR 2.4, all EC cases) and irregular periods (OR 3.1, all EC cases) (Fearnley et al. 2010).

\section{Ovarian cancer}

According to a recent report from FIGO, ovarian cancer is the seventh most common cancer in women worldwide (Prat 2013). In the UK, it is the fifth most common female cancer (http://www.cancerresearchuk.org/) consistent with higher incidence in high-resource countries (Ferlay et al. 2010). The aetiology of ovarian cancer is not fully understood and work on predictive biomarkers has been hampered by failure to separate results on the basis of histological subtype (Sieh et al. 2013a). Approximately $90 \%$ of ovarian tumours are carcinomas (malignant epithelial tumours) with five main types being distinguished based on histopathology and molecular genetic analysis (Prat 2012, Tan et al. 2013). Although historically often treated as a single disease entity, new evidence has revealed that histologically similar ovarian cancers may differ in their tissues of origin, their genetic abnormalities and their responsiveness to chemotherapy (Tan et al. 2011). A recent GWAS study reported six loci that were associated with subtype-specific epithelial ovarian cancer risk (Earp et al. 2013) underlining the importance of redefining the origins of some subtypes. The Australian Ovarian Cancer Study group reported strikingly similar patterns of risk for serous ovarian and fallopian tube cancers and different results for primary peritoneal cancers suggesting that the former may be linked (Jordan et al. 2008). Additional studies have reported that the protective effect of tubal ligation is subtype specific with risk reduction for invasive endometrioid and clear cell cancers (Sieh et al. 2013b). Studies on women with BRCA1/BRCA2 mutations have provided convincing evidence that highgrade serous cancers can arise from cells within the fallopian tube (reviewed in Berns \& Bowtell (2012)).

Non-epithelial ovarian cancers include sex cord tumours, germ cell tumours, yolk sac tumours and ovarian-Leydig tumours - together they account for $\sim 10 \%$ of ovarian cancers (Van Nieuwenhuysen et al. 2013). The majority are granulosa cell tumours (GCTs) with the adult form typically detected in women in their 1950s who present with post-menopausal vaginal bleeding (Schumer \& Cannistra 2003). Adult GCTs are thought to arise from granulosa cells in late pre-ovulatory follicles and similar to their pre-malignant counterparts they secrete steroids including oestrogen, and in rare cases, patients may present with evidence of hyperandrogenism (Vera et al. 2013).

As with other female cancers, the strongest risk factor for development of ovarian cancer is age. In the UK, between 2008 and 2010, 75\% of cases were diagnosed in women aged 55 and over (http://www.cancerresearchuk. org/). A large Swedish study has reported that women who were admitted to hospital for ovarian cysts before the age of 29 were at increased risk of ovarian cancer later in life (Borgfeldt \& Andolf 2004). Ovarian cancer risk is consistently reported as being reduced by factors that interrupt ovulation, including use of oral contraceptives, pregnancy or breastfeeding (Modugno et al. 2012) as well as tubal ligation with the latter most closely associated with endometrioid tumours (Rice et al. 2013). Pooled data from 12 prospective cohort studies in North America and Europe identified 2000 ovarian epithelial cancers in approximately half a million women. They reported an association between height $>1.7 \mathrm{~m}$ and ovarian cancer risk especially in pre-menopausal women (Schouten et al. 2008). Gonadal hormones stimulate growth at puberty, hence an association between height and risk may be consistent with hormone action.

In their 2012 review of the epidemiological evidence that androgens might play a role in development of epithelial ovarian cancers, Modugno et al. argued that although some epidemiological evidence supported a role for androgens in development of disease, there were also studies that did not support this assertion (reviewed in Modugno et al. (2012)).

Results from the Million Women Study reported risks associated with use of HRT in post-menopausal women. Current users were significantly more likely to develop ovarian cancer than never users but in past users there was no elevation of risk. In current users, risks varied considerably according to cancer histology (Beral et al. 2007). Additional evidence for hormonal associations with risk may be inferred from the reported association between development of endometriosis, an oestrogendependent inflammatory disorder and ovarian cancer. Pooled analysis of 13 case-control studies found that endometriosis was associated with an increased risk of clear cell, low-grade serous and endometrioid invasive but not mucinous tumours (Pearce et al. 2012).

Many patients with symptoms of PCOS (see above) have elevated circulating concentrations of androgens that

Published by Bioscientifica Ltd. 
may be associated with development of hirsutism (Franks 1995). Although some studies have reported increased risk of ovarian cancer in women with PCOS or hirsutism, results were based on very small numbers of patients. In a population-based Australia-wide study of $\sim 1500$ women with a new diagnosis of invasive epithelial ovarian cancer or borderline malignant tumour, there was no evidence that excess androgens due to PCOS or treatment with the synthetic androgen Danazol were correlated with overall risk of ovarian cancer but PCOS did increase the risk of borderline tumours (Olsen et al. 2008). However, in a small study of women taking Danazol as a treatment for endometriosis, Danazol use was associated with a 3.2-fold increased risk of ovarian cancer (Cottreau et al. 2003).

\section{Structure and function of ARs}

Androgenic regulation of gene expression is mediated via the binding of androgens to their cognate AR (NR3C4). The gene encoding human $A R$ is located on the $\mathrm{X}$ chromosome (Lubahn et al. 1988). Cloning has identified eight exons with conserved domains in common with other steroid hormone receptors (Kuiper et al. 1989). The full-length human AR protein (110 kDa) has an extensive amino-terminal domain (NTD), a DNA-binding domain, a hinge region and a ligand-binding domain. Intra- and inter-molecular interactions between domains are important for the receptor's activation capacity (reviewed in Claessens et al. (2008)).

One of the most studied polymorphisms of the AR NTD is the CAG-repeat sequence encoding poly-glutamine repeats (Spada et al. 1991). The length of the CAG-repeat region correlates inversely with AR transactivation capability (Chamberlain et al. 1994). Notably, an association has been reported between the number of CAG and GGN repeats in the NTD and the progression state of EC, with a prevalence of short repeats in more benign tumours (McGrath et al. 2006, Rodríguez et al. 2006). However, it should be noted that a later study reported a weak association between the CAG repeats and EC risk (Yang et al. 2009). Epigenetic regulation of the $A R$ gene has also been implicated in endometrial malignancy, with hypermethylation of a $\mathrm{CpG}$ region spanning the transcription start site being associated with $A R$ gene inactivation in EC patients (Sasaki et al. 2000). Loss of AR expression in stages III and IV of the disease also correlates with the methylation status of this $\mathrm{CpG}$ region, with cancerous and normal tissues from the same patient having a significant difference in both methylation status and the presence/absence of AR expression (Sasaki et al. 2000).
AR is the target of several post-translational modifications including acetylation, phosphorylation, methylation, ubiquitination and sumoylation (reviewed in Coffey $\&$ Robson (2012)). AR sumoylation has been demonstrated to enrich $\mathrm{AR}$ in the nuclear matrix under conditions of cellular stress, causing attenuation of the transcriptional activity of AR, contributing to defective androgen signalling in cancer (Poukka et al. 2000, Rytinki et al. 2012). Phosphorylation of serine residues in the NTD of AR can result from ligand activation as well as growth factor and other signalling cascades, which in turn can influence the secondary structure of the domain (reviewed in Kumar \& McEwan (2012)). It is notable that phosphorylated AR proteins have been localised in both ovarian tissues (McEwan et al. 2010) and recently investigated in the context of breast cancer (Ren et al. 2013).

\section{Expression of ARs in the non-malignant endometrium and ovary}

Expression of ARs has been documented throughout the female reproductive system including the ovary (Saunders et al. 2000), fallopian tube (Horne et al. 2009) and endometrium (Marshall et al. 2011) consistent with a role for local or peripheral androgens in modulating the function of these tissues.

\section{Endometrium}

It has been reported that ARs are expressed in the endometrium throughout the menstrual cycle (Mertens et al. 2001, Apparao et al. 2002, Marshall et al. 2011). In our own studies examining immunoexpression of AR in fullthickness sections of human endometrium (see supplementary Fig. 1 in Marshall et al. (2011)), we have noted the highest levels of immunoexpression in the stromal cells within the upper, functional, layer during the oestrogendominated proliferative phase with immunopositive stromal cells in the basal layer throughout the cycle regardless of stage. Although some authors have claimed that AR is detected in glandular epithelium throughout the menstrual cycle (Horie et al. 1992), we and others have reported that immunoexpression is up-regulated in the glandular epithelium in the mid/late secretory phase at a time when progesterone concentrations are falling due to the demise of the corpus luteum (Marshall et al. 2011).

The generation of a transgenic $A r$ reporter mouse, which expressed a luciferase reporter gene under the control of activated endogenous AR, has revealed high AR activity in both the uterus and the ovary,

Published by Bioscientifica Ltd. 
demonstrating the direct action of androgens in these tissues (Dart et al. 2013). Studies on AR knockout (ARKO) female mice have shown that they have normal reproductive tracts under macroscopic examination but are subfertile (Hu et al. 2004). A study utilising reciprocal paired ovarian transplantation between $\mathrm{Ar}^{+/+}$and $\mathrm{Ar}^{-/-}$mice revealed that host $A r^{-/-}$female mice with $\mathrm{Ar}^{+/+}$ovarian transplants had defective uterine growth consistent with an intrauterine role for androgens in this species (Walters et al. 2009).

\section{Ovary}

ARs are expressed in somatic cells within the human ovary in both foetal and adult life (Saunders et al. 2000, Fowler et al. 2011). It is notable that ARs are present in cells of the surface epithelium, as malignant transformation of this cell type has been implicated in development of epithelial ovarian cancers following formation of inclusion cysts (Rabban \& Bell 2005) although which subtypes this is associated with is currently being re-evaluated (Berns \& Bowtell 2012). In all species examined to date, intense AR immunoexpression has been documented in adult granulosa cells (Saunders et al. 2000). In primate ovaries, expression of AR was most abundant in immature follicles (Hillier et al. 1997).

ARKO mice generated by targeted deletion of exon 2 have longer oestrous cycles and fewer corpora lutea, and when superovulated they produced fewer oocytes compared with WTs. Intense granulosa cell apoptosis was detected in pre-ovulatory follicles (Hu et al. 2004). Similarly, ARKO mice with an inframe deletion of exon 3 (DNA-binding zinc finger 2) are reported to be subfertile with reduced ovulation associated with morphologically unhealthy antral follicles (Walters et al. 2007). Female mice with targeted deletion of $\mathrm{Ar}$ in granulosa are also subfertile confirming the importance of AR expression in granulosa cells for normal ovarian function (Walters et al. 2012).

Thus, androgen action is an important feature of normal reproductive function and AR-dependent signalling influences uterine growth and ovarian function.

\section{Androgen action in EC and ovarian cancer}

\section{AR expression in EC}

There have been limited studies describing the expression of AR in EC. Horie et al. (1992) described positive immunostaining for AR in glandular cells and in the solid mass in a small sample set of grade II adenocarcinomas. Ito et al. (2002) compared the expression of AR and $5 \alpha$-reductase types 1 and 2 in 44 cases of endometrioid adenocarcinomas. Positive immunostaining for AR was detected in stromal cells and in $88.6 \%$ of carcinoma cells, while $5 \alpha$-reductase types 1 and 2 were detected in $\sim 80 \%$ of carcinoma cells. Analysis of endometrioid carcinoma tissue homogenates confirmed mRNA expression of $A R, 5 \alpha$-reductase types 1 and 2 in the majority of cases (Ito et al. 2002). By contrast, Sasaki et al. (2000) detected AR-positive cells in only 19 of 89 EC tissues, although the cancer samples investigated were not restricted to a single histological type. A recent analysis of uterine sarcomas failed to identify AR expression in uterine carcinosarcoma, leiomyosarcoma or endometrial stromal sarcoma (Koivisto-Korander et al. 2011).

AR protein levels are reported to decline as EC progresses from well- to poorly differentiated tumours (Kato \& Seto 1985). In our own laboratory, we consistently detect AR in the nuclei of epithelial and stromal cells in stage I tumours graded as well or moderately well differentiated (Fig. 1A, B, C and D). Notably, AR staining was not always evenly distributed within all epithelial cells (Fig. 1C) and was sporadic in poorly differentiated tumours that lacked a defined epithelial compartment (Fig. 1F). Nuclear AR was detected in stromal cells in all stages but vascular and immune cells were immunonegative (asterisks in Fig. 1D and E).

Results reported for some endometrial cell lines may be unreliable due to cross-contamination with other cancer cells (Korch et al. 2012). The most widely used cell line, the Ishikawa cell line (available from ECACC/ATCC), was derived from a moderately differentiated stage II endometrial adenocarcinoma tumour (Nishida et al. 1996). We, and others (Lovely et al. 2000), have consistently found that this cell expresses AR, ER $\alpha$ (ESR1) and ER $\beta$ (ESR2). Notably, it has been reported that AR protein expression in this transformed epithelial cell can be induced by oestradiol $\left(\mathrm{E}_{2}\right)$ or DHT but is downregulated by medroxyprogesterone acetate (MPA) or the anti-androgen hydroxyflutamide (Apparao et al. 2002).

\section{AR expression in ovarian cancer}

There have been a number of studies showing overexpression of $\mathrm{AR}$ in ovarian cancer with papers also reporting the impact of androgens on gene expression and survival of ovarian cancer cell lines (reviewed in Modugno et al. (2012)). In a recent study, positive AR immunostaining was reported in two sets of ovarian cancer tissues. The histology of 46 serous epithelial cancers

Published by Bioscientifica Ltd. 

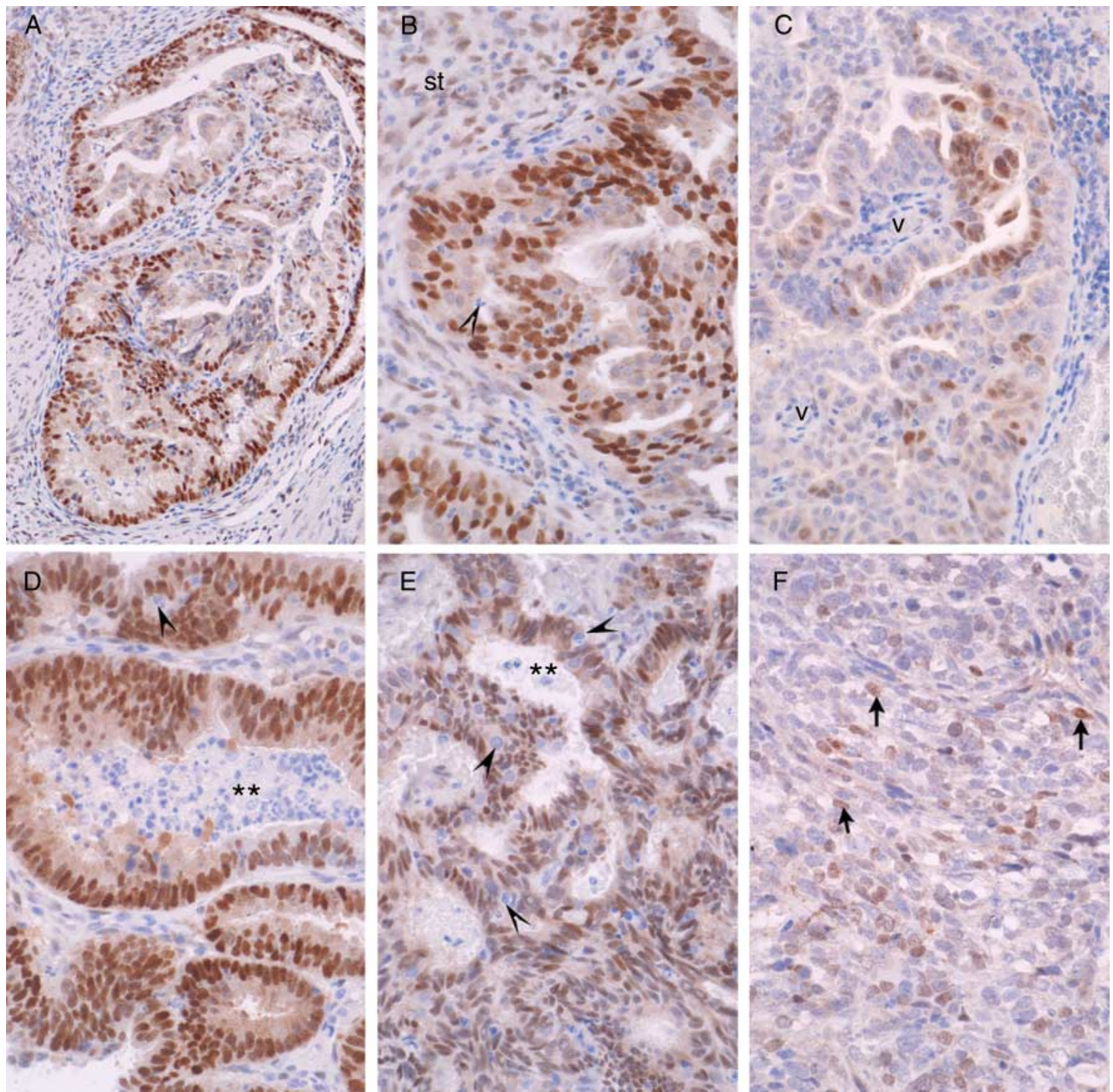

\section{Figure 1}

Androgen receptor expression in stage I endometrial adenocarcinomas. Endometrial cancer cells from a dataset described previously in Collins et al. (2009) were immunostained using rabbit anti-human AR (Abcam, Cambridge, UK) in 1:100 dilution (see Marshall et al. (2011), with detection using DAB as described in Collins et al. (2009)). Intense nuclear expression of $A R$ was detected in epithelial cells in cancers graded as well (A and $B$ ), moderately ( $C$ and $D$ ) and poorly (E) differentiated. Epithelial AR staining was heterogeneous with some epithelial cells immunonegative for AR

(patients aged 27-86) as well as 23 samples with matched metastases was assessed and the majority demonstrated moderate to strong nuclear immunostaining for AR (Butler et al. 2013). This study also examined expression of an $A R$ nuclear chaperone called SGTA and reported a correlation between AR:SGTA ratio and disease subtype (Butler et al. 2013). In epithelial ovarian cancers, it has been reported that women with shorter CAG repeats in the NTD of their Printed in Great Britain (arrowheads). The number of immunopositive cells was highly variable and immunopositive cells were not evenly distributed throughout the section (see C). Immunopositive fibroblasts were also noted within the stroma (st), but putative immune cells within blood vessels $(v)$ were immunonegative $\left.{ }^{* *}\right)$. In poorly differentiated tumours (F) that lacked a defined epithelial compartment, AR immunostaining was sporadic (arrows). Magnifications: $(A$ and $E), \times 20$ and $(B, C, D$ and $F), \times 40$.

AR had decreased overall survival (Li et al. 2003). Other reports examining expression of the AR co-activator AIB1 (NCOA3) have reported that isoforms of the protein with shorter CAG repeats are associated with poor prognosis (Li et al. 2005). Other AR co-activators implicated in ovarian cancers such as p44/Mep50/WDR77 may also act as co-activators for oestrogen receptors, making it difficult to know whether over-expression in ovarian cancers and

Published by Bioscientifica Ltd. 
associated increases in cell proliferation and invasion are AR mediated (Ligr et al. 2011).

\section{Androgen metabolism and the impact on androgen bioavailability}

The greatest concentrations of circulating androgens are precursors/prohormones that can be activated locally by the action of $5 \alpha$-reductase (testosterone to DHT) and $17 \beta$-hydroxysteroid dehydrogenases (17 $\beta \mathrm{HSD}$ ) enzymes (A4 to testosterone). The expression and activity of steroid-metabolising enzymes determine the local bioavailability of androgens and thus affect AR-dependent signalling in normal and malignant tissues. The transcriptional activity of ARs is altered by endogenous androgens such as testosterone and DHT. DHT is the most potent endogenous AR agonist, while A4 and DHEA have extremely low binding affinity for AR (Avances et al. 2001). Studies investigating $5 \alpha$-reductase protein expression in the endometrium have reported expression in epithelial cells alone (Ito et al. 2002) or both stromal and epithelial cells (Carneiro et al. 2008). In studies using human endometrial explants (Rose et al. 1978), $5 \alpha$-reductase has also been shown to reduce testosterone to DHT consistent with local androgen activation in intact tissue. The endometrium is also reported to convert the adrenal androgen DHEAS to DHEA and A4 (Hausknecht et al. 1982). Interestingly, a recent study has shown that A4 up-regulates aromatase mRNA expression in human endometrial stromal cells and explants (Bukulmez et al. 2008) underlining the importance of local bioavailability and metabolism of androgens in modulating the steroid microenvironment in the endometrium.

\section{Tumour-associated steroid metabolism in EC and ovarian cancer}

Dysregulation of enzymes that mediate steroid metabolism is an important feature of the pathophysiology of reproductive malignancies. Rizner et al. (2006) showed that dysregulation of AKR1C3 (also known as 17ßHSD5), which converts A4 to testosterone, is associated with EC with increased mRNA expression in malignant endometrium compared with normal endometrium. A recent review from the same group concluded that due to the limitations of the available studies on AKR1C3 protein expression, the importance of AKR1C3 in EC pathophysiology requires further investigation (Rizner 2013). Sinreih et al. investigated the expression of progesterone synthesis and metabolism genes in 47 stage I EC tumours and found decreased expression of CYP11A1 and STAR in EC tumours, which may indicate that local steroid metabolism/conversion rather than circulating hormone concentrations are important in determining intratumoural hormone bioavailability. Interestingly, a 3.7-fold decrease in SRD5A2 expression and a threefold increase in $H S D 17 B 2$ expression in tumour compared with adjacent control endometrial tissue were also reported consistent with a potential for altered intra-tumoural androgen metabolism (Sinreih et al. 2013). This altered expression would be consistent with decreased activation of androgens as a result of less conversion of testosterone to DHT ( $5 \alpha$-reductase activity) and increased conversion of testosterone to A4 (17 $\beta \mathrm{HSD} 2$ activity) within EC. Interestingly, A4 is the preferential substrate for aromatase, which might suggest that altered metabolism of androgens favours an oestrogenic pathway. Notably, concentrations of $\mathrm{E}_{2}$ measured in EC tumour tissues are higher than those of disease-free endometrium (Berstein et al. 2003).

The activity of steroid sulphatase (STS) enzymes may also increase bioavailable androgens through de-sulphation of DHEAS to DHEA. Expression and activity of STS has been reported in endometrial carcinoma cell lines (Smuc et al. 2006, Fournier \& Poirier 2009). STS activity is reported to be higher in EC tissue compared with normal endometrium (Yamamoto et al. 1993), and more recent studies have reported that STS mRNA levels are increased in tumoural endometrial tissues compared with peri-tumoural endometrial tissues (Lepine et al. 2010). In addition, Abulafia et al. (2009) reported significantly increased DHEAS sulphatase activity in stage I endometrioid carcinoma compared with normal endometrium consistent with a role for increased activation of androgen precursors in EC.

Variants in genes involved in the synthesis and action of sex steroid hormones are likely to be important in the aetiology of EC. The association between polymorphisms in genes encoding sex steroid enzymes and steroid receptors and EC risk has been examined in a number of studies with the focus directed towards genes involved in the oestrogen biosynthesis pathway. An association between single nucleotide polymorphisms (SNPs) in CYP19A1 with oestrogen concentrations (both oestrones $\left(\mathrm{E}_{1}\right)$ and $\mathrm{E}_{2}$ ) and oestrogen:testosterone ratios has been described in post-menopausal women (Dunning et al. 2004). Olson et al. (2007) reviewed the association between variants in steroid biosynthetic genes, circulating hormones and EC risk by summarising available data for seven genes in the oestrogen biosynthesis pathway. Variants of CYP11A1, CYP17A1 and HSD17B1 were not associated

Published by Bioscientifica Ltd. 
with altered levels of progesterone, androgens or oestrogens; CYP17A1 variants were associated with a decreased risk of EC and CYP19A1 variants with an increased risk of EC (Olson et al. 2007). A recent case-control study of polymorphisms in $391 \mathrm{EC}$ cases and 712 individually matched controls found that CYP19A1 variants are associated with an increased risk of EC (Lundin et al. 2012). Interestingly, in an extensive analysis of common genetic variation of 36 sex hormone-related genes by Yang et al. (2010), genetic variation in $A R$ was significantly associated $(P=0.006)$ with an increased risk of EC.

Alterations in the expression/activity of ovarian steroidogenic enzymes may also contribute to ovarian cancer risk. GCTs are rare (2-5\% of all ovarian cancers) but characterised by their ability to synthesise and secrete steroids including oestrogens and androgens with some post-menopausal patients presenting with symptoms including hirsutism and virilisation (Schumer \& Cannistra 2003). In mice, over-expression of human HSD17B1 resulted in development of an androgen-dependent ovarian benign serous cystadenoma phenotype in adulthood (Saloniemi et al. 2007). Beesley et al. (2007) assessed putative SNPs in genes involved in steroid hormone synthesis and found an increased risk of epithelial ovarian cancer associated with a SNP in the $5 \alpha$-reductase gene (SRD5A2 V89L). However, a subsequent analysis by the ovarian cancer consortium in a large pooled sample of 4624 invasive epithelial cancer cases and 8113 controls found no association between SRD5A1 and ovarian cancer risk (Ramus et al. 2008).

Taken together, these data suggest that dysregulation of androgen biosynthesis is a feature of the pathophysiology of EC. The association between ovarian cancer and altered steroid metabolism is less clear with interpretation limited by heterogeneity of the disease.

\section{Androgens and ARs as a therapeutic target in EC and ovarian cancer}

\section{Endometrial cancer}

Despite the potential associated risks of elevated androgens (described above), androgens receptors may be a potential therapeutic target in EC. For example, testosterone treatment of post-menopausal women does not appear to induce endometrial stimulation and decreases the proliferative effect of $\mathrm{E}_{2}$ (Zang et al. 2007). Studies on cancer cell lines have shown that AR-dependent signalling inhibits proliferation of cells derived from breast and endometrial tumours (Hackenberg \& Schulz 1996).
In a mouse model of endometrial carcinogenesis, the synthetic androgen Danazol significantly decreased expression of the proliferation marker PCNA and the incidence of endometrial hyperplasia (Niwa et al. 2000).

Treatment of primary endometrial stromal cells with DHT alters expression of genes involved in proliferation, cell survival and migration, all of which are likely to be dysregulated in tumours (Marshall et al. 2011). Therefore, targeting AR-regulated transcription could be a productive therapy for preventing disease progression. Interestingly, cyclin D1 (CCND1), a protein which is important in regulating the cell cycle is reported to be AR regulated (Lanzino et al. 2010). Expression of cyclin D1 has been linked to breast cancer growth and progression, and studies on breast cancer cells have revealed that CCND1 promoter activity can be inhibited by DHT-activated AR (Lanzino et al. 2010). CCND1 expression is significantly associated with EC grade (Moreno-Bueno et al. 2003) with a recent study suggested that cyclin D1 may be a prognostic marker for endometrial diseases with overexpression of cyclin D1 in EC and atypical complex hyperplasia (Liang et al. 2013). A recent study investigating changes in Ishikawa cells in response to tamoxifen using gene expression profiling found that this synthetic SERM significantly up-regulated CCND1 (Tamm-Rosenstein et al. 2013). As tamoxifen exposure is associated with an increased risk of EC, androgen-based therapies that promote down-regulation of CCND1 expression may decrease risk of disease development.

Prostate-specific antigen (PSA/KLK3) is an androgenregulated gene that has been extensively investigated in the context of prostate cancer (Montgomery et al. 1992). Mhawech-Fauceglia et al. (2008) assessed PSA expression in 49 endometrial adenocarcinoma tissue specimens. The study reported weak expression of PSA in the glands of normal endometrium and that $67.7 \%$ of EC tissues had no/weak staining for PSA. High PSA mRNA levels were associated with stage I disease but not with tumour grade or subtype. Interestingly, multivariate survival analysis associated loss of PSA expression with worse disease-free survival (Mhawech-Fauceglia et al. 2008). Circulating levels of PSA are increased in women with PCOS and are directly correlated with hyperandrogenism (Mardanian \& Heidari 2011). As AR expression decreases with progression of EC, loss of AR-regulated PSA may be important in EC disease progression.

Mutations in the oncogene KRAS are associated with EC and can lead to stimulation of the ERK1/2 signalling pathway in the absence of stimuli and activating KRAS mutations have been identified in precursor lesions for

Published by Bioscientifica Ltd. 
ECs (Dobrzycka et al. 2009). A recent integrated analysis of $K R A S$ CNA and mutations found that increased KRAS copy number and mRNA expression but not KRAS mutations were associated with EC disease progression and poor disease-specific survival (Birkeland et al. 2012). The authors report that mRNA expression levels and KRAS amplification were increased significantly in metastatic compared with primary lesions consistent with involvement of KRAS alterations in disease progression (Birkeland et al. 2012). In a recent study, KRAS protein expression was reported to be decreased by AR signalling in ER-, PRand AR + breast cancer cells (Lyu et al. 2014), which may indicate a further target for androgen therapy in EC.

The tumour suppressor gene phosphatase and tensin homologue deleted on chromosome 10 (encoded by PTEN) regulates cell growth, apoptosis and proliferation (Zhao et al. 2004). Mutations in PTEN are common in EC and this leads to inactivation and loss of PTEN expression, which is an early diagnostic marker for endometrial pre-cancers (Mutter et al. 2000a). In the normal endometrium, PTEN appears to be under hormonal control (Mutter et al. 2000b). Guzeloglu-Kayisli et al. (2003) reported that $\mathrm{E}_{2}$ promoted PTEN phosphorylation and that progesterone increased PTEN protein expression in isolated endometrial, stromal and epithelial cells. The impact of androgens on PTEN expression in the endometrium is unknown and likely to be cell context dependent as AR-dependent signalling inhibits PTEN expression in prostate cancer cells whereas stimulation of AR signalling up-regulates PTEN expression in breast cancer cells (Wang et al. 2011).

AR-dependent regulation of gene expression may play a role in progression of EC; however, as responses are likely to be cell context dependent, further investigation is required to fully understand which target genes are affected.

\section{Ovarian cancer}

In contrast to the potential anti-proliferative role of androgens in breast and EC, androgens may promote growth of some ovarian cancers and anti-androgen therapy has been proposed. In vitro, androgens promote proliferation of ovarian surface epithelial (OSE) cells and human ovarian cancer cells (Syed et al. 2001). Some studies on androgen action in ovarian carcinomas may need to be treated with caution as some of the established cell lines may not be of ovarian cancer origin (Korch et al. 2012). In a recent review, Modugno et al. (2012) summarised the evidence that therapies targeting ARs for treatment of women with ovarian cancer might be a promising strategy. They highlighted the small scale of most trials; they had used anti-androgens for treatment of women with recurrent cancer and variable results were obtained. When Elattar et al. (2012) tested the impact of DHT on cell division in primary ovarian epithelial cancer cells isolated from the ascites of 11 patients with advanced primary ovarian cancers, they recorded variable concentrations of $A R$ mRNA and an increase in S-phase cells, which was abrogated by treatment with anti-androgen. They also noted a decrease in AR positive staining of tumours after chemotherapy and concluded that, although there might be a subgroup of patients that could benefit from antiandrogen therapy, this might be best administered early in the treatment regime.

In granulosa cell cultures, Stocco et al. have reported that testosterone, but not DHT, alters expression of aryl hydrocarbon receptor (AHR) and liver receptor homologue 1 (LRH1 (NR5A2)) with an AHR-dependent interaction between AHR and AR leading to increased expression of the LRH1 gene (Wu et al. 2013). As LRH1 is an orphan receptor that has been implicated in promoting invasion and migration of breast cancer cells independent of oestrogen action (Chand et al. 2010), any increase in expression as a result of androgen action might promote invasiveness of granulosa cells and it is notable that LRH1 level is elevated 30-fold in GCTs (Chand et al. 2013). Consistent with their cell of origin, analysis of GCTs and derived cell lines (COV434 and KGN) confirmed expression of several steroid hormone receptors including $A R$ and $E R \beta$ (Alexiadis et al. 2011). Notably, treatment of a small group of patients with diagnosis of a GCT with aromatase inhibitors has reported positive results (Alhilli et al. 2012).

Microarray experiments using DHT-stimulated OVCAR3 cells (established from ascites of a woman with an ovarian adenocarcinoma) reported that 121 genes were up-regulated (Sheach et al. 2009) including Ras-related protein, RAB25 (RAB25), a small GTPase implicated in vesicle trafficking and cancer metastasis previously shown to be over-expressed in aggressive cancers (Cheng et al. 2004). A recent report highlighted a role for promoter methylation in the regulation of expression of the AR co-activator melanoma-associated antigen 11 (MAGEA11) in ovarian and other cancers, a finding that is important as expression is correlated with poor prognosis (James et al. 2013). In a recent study of $\sim 3000$ women with a mean age of $\sim 57$ years, invasive epithelial ovarian cancer tissues were examined to determine whether there was a link between expression of progesterone receptor or oestrogen receptor $\alpha$ and subtype-specific survival (Sieh et al. 2013a);

Published by Bioscientifica Ltd. 
although the study did not measure AR, it reported that expression of PR (PGR) was associated with improved survival with high-grade serous carcinoma. A number of clinical trials have used endocrine therapies to reduce oestrogen production (e.g. aromatase inhibitors) or receptor activation with mixed results (reviewed in Modugno et al. (2012)). Treatment of women with aromatase inhibitors has the potential to raise local and peripheral androgens by blocking their conversion to oestrogens, hence further studies are needed to see if changes in bioavailable androgens as a result of this treatment regime contribute positively or negatively to disease outcome.

\section{Insights into the role of androgens in breast and prostate cancers}

Studies investigating the role of AR in breast cancer suggest that focusing on AR-dependent transcriptional activity alone will not be sufficient to fully understand how endogenous androgenic ligands, or the use of AR modulators, might alter cancer development/progression in EC or ovarian cancer. For example, studies on the breast have considered two aspects: anti-androgenic effects of the progestin MPA (Ochnik et al. 2014) and crosstalk between $\mathrm{AR}$ and $\mathrm{ER} \alpha$ signalling due to overlapping binding sites within DNA (Need et al. 2012, Ochnik et al. 2014). Studies on breast tissue from post-menopausal women showed that DHT had an anti-proliferative effect that was opposed by MPA (a component of some HRT formulations) due to destabilisation of AR and increased proliferation (Ochnik et al. 2014). Following reports that DHT could induce proliferation of $\mathrm{ER} \alpha$-positive and $\mathrm{ER} \alpha$-negative breast cancer cell lines via distinct mechanisms (Lin et al. 2009a), Need et al. (2012) used the ChIP-Seq technology to demonstrate reciprocal interference between DHT- and $\mathrm{E}_{2}$-induced gene expression profiles and altered expression of genes such as progesterone receptor, FKBP5 and CXCL12, all of which are considered as classically regulated by oestrogens. Importantly, we have previously reported significantly decreased concentrations of ER $\alpha$ mRNA in poorly differentiated tumours compared with both well- or moderately differentiated grade I ECs and demonstrated that ER $\alpha$ protein expression was low/absent in poorly differentiated tumours (Collins et al. 2009). We postulate that changes in the relative expression ratios of AR and $\mathrm{ER} \alpha$ are likely to impact on the ability of androgens to activate/repress expression of genes implicated in key processes such as cell migration, proliferation and apoptosis.

Studies on prostate cancer cells suggest that the transforming growth factor $\beta$ (TGF $\beta$ ) signalling molecule
Smad3 can transactivate AR and it has been reported that DHT can suppress the ability of TGF $\beta$ to promote apoptosis. Additional data examining the AR-associated protein HIC5 (TGFB1I1) in this interaction highlight a complex interplay between these signalling pathways and cancer progression (Wang et al. 2005, Song et al. 2010). Androgen signalling may also influence epithelial to mesenchymal transition (EMT), a critical event in cancer metastasis. Recent studies on prostate cancer epithelial cells indicate that androgens induce EMT, migration and invasion of prostatic epithelial cells (Zhu \& Kyprianou 2010).

In addition to transcriptional crosstalk between ER $\alpha$ and $\mathrm{AR}$, testosterone has been shown to induce ERK and Akt phosphorylation by activating the $E R \alpha$ splice variant $\mathrm{ER} \alpha 36$ in the ER $\alpha$ - and AR-EC cell line Hec1A (Lin et al. $2009 \mathrm{~b}$ ). Thus, androgens may stimulate activation of signalling pathways via $E R$ splice variants in the absence of AR that may be important in the context of decreased $\mathrm{AR}$ expression with EC disease progression.

\section{Future perspectives}

To date, information on the potential impact(s) of androgens on aetiology and prognosis in EC and ovarian cancer has largely focused on the potential for intratumour biosynthesis of ligand and on the use of transformed cell lines for examination of androgendependent gene expression (see above).

Androgen-dependent signalling may affect the expression of oncogenes, tumour suppressor genes, cell cycle regulators and metastasis-associated genes that may impact on disease progression. Information from studies on other cancers suggest an extensive capacity for crosstalk between steroid receptors. Therefore, detailed sequencing analysis will be required to understand the distinct gene sets regulated by oestrogens, androgens and progestogens in a given tissue, and measuring intra-tissue levels of sex steroid hormones will be required to estimate the possible converging signalling inputs that may influence malignant development within tissues. The effect of AR-dependent signalling will be determined by AR expression, cell context expression of co-regulatory proteins, expression and activity of other sex steroid receptors that may compete for DNA-binding sites on the promoters of target genes as well as the local bioavailability of ligand for the receptor. In order to understand the relative contribution of androgen action to risk of malignancy, the balance in expression and activity of steroid enzymes within the tissue, which determines AR ligand bioavailability, needs further

Published by Bioscientifica Ltd. 
investigation. testosterone and A4 can be interconverted by the action of $17 \beta \mathrm{HSD}$ isozymes and testosterone can also be reduced by $5 \alpha$-reductase to more potent androgen DHT. While DHT is non-aromatisable, both testosterone and A4 can be aromatised to active oestrogens. Thus, a better understanding of the relative contribution of $5 \alpha$-reductase and aromatase enzyme activity is required in order to ascertain whether increased androgen concentrations have a direct effect on the tissue or whether they are acting as pro-hormones to increase high-risk oestrogen exposure.

Studies on the role of androgens in the context of ovarian cancer would be particularly timely as the new findings, suggesting that many forms of epithelial ovarian cancer previously thought to originate from OSE cells may actually derive from extra-ovarian sources (reviewed in Kurman \& Shih Ie (2011)). For example, cells within the fallopian tube epithelium have been proposed as the cell type(s) contributing to low- and high-grade serous carcinomas (Piek et al. 2001). A mouse model using a conditional double KO of Dicer (Dicer1) and Pten demonstrated that high-grade serous cancers develop in the fallopian tube and metastasise to the ovary (Kim et al. 2012). Although there is still evidence to support OSE cells as the originating cell type for some ovarian cancers (Auersperg 2013), the fact that both OSE cells and cells within the fallopian tube epithelium express AR (Edmondson et al. 2002, Horne et al. 2009, Mendez et al. 2013) highlights the potential for androgens to modulate disease development and progression. Stem-like epithelial cells from the distal end of the fallopian tube capable of clonal growth and self-renewal have also been identified which may play a role in the initiation of serous tumours, although the impact of androgens on this cell population has not been investigated (Paik et al. 2012). The associated increased risk of ovarian cancer in women with endometriosis (Pearce et al. 2012) may suggest that AR-positive cells in endometrial tissue might also contribute to development of ovarian cancer as AR protein and mRNA have been reported in both eutopic endometrium and peritoneal lesions in women with peritoneal endometriosis (Carneiro et al. 2008).

Improving our understanding of the tissue-specific effects of AR signalling may lead to the application of novel therapeutic strategies such as combination therapies with aromatase inhibitors or SERMs (see data above on crosstalk with $\mathrm{ER} \alpha$ ). In addition, a novel $45 \mathrm{kDa}$ AR isoform (AR45) that was discovered in 2005 was found to be expressed in the uterus and shown to be a negative regulator of AR by interacting with the AR NTD (Ahrens-Fath et al. 2004).
Elucidating the expression of this variant in normal and malignant reproductive tissues may lead to the identification of a potential therapeutic target.

Using computational pharmacophore modelling and virtual screening, second-generation anti-androgens have been developed which could be of therapeutic benefit in treating AR-dependent ovarian cancers (Voet et al. 2013). Furthermore, the generation of selective AR modulators (SARMs) has revolutionised the potential manipulation of androgenic stimulation in a therapeutic context (Gao \& Dalton 2007). The important role played by androgens in regulation of muscle mass and aetiology of prostate cancer has led to development of compounds that are classified as SARMs and are designed to maintain well-being in men without causing prostatic hyperplasia or malignancy. A recent review highlighted positive impacts of SARMs on cancer-associated muscle wasting (Dalton et al. 2013). Although limited evidence has been presented to date, press reports on one SARM (Enobosarm, Gtx, Inc., Memphis, TN, USA) highlight preliminary (unpublished) data of a trial testing use as a therapy for women with metastatic breast cancer (http://phx.corporate-ir. net/phoenix.zhtml?c=148196\&p=irol-newsArticle\&ID= 1884210). The use of SARMs could be of great potential therapeutic benefit in the treatment of gynaecological malignancy. A SARM with the anti-proliferative effects of androgens in the endometrium but without the proliferative effect of androgens on OSE cells could have potential therapeutic merit in treatment of both EC and ovarian cancer.

\section{Summary and conclusions}

The impact of androgen action in EC and ovarian cancer is poorly understood. Epidemiological evidence suggests that increased risk of EC is associated with increased exposure to androgen action through elevated circulating concentrations of testosterone, conditions that may cause hyperandrogenism such as PCOS, as well as genetic variation in the AR. Cell and animal studies suggest that androgens may be a beneficial therapeutic target in EC with the potential to inhibit proliferation and promote changes in expression of oncogenes, cell cycle regulators, tumour suppressor genes and metastasis-associated genes.

The evidence for a role for androgen action in ovarian cancer is less clear and is limited by the heterogeneous nature of the disease. Obesity is associated with an increased risk of ovarian cancer and some studies suggest that obesity may promote a hyperandrogenic state. In addition, limited studies suggest that exposure to the

Published by Bioscientifica Ltd. 
synthetic androgen Danazol increases risk of ovarian cancer. Analyses of SNPs in genes associated with the androgen biosynthetic pathway suggest that variants of SRD5A1 may be associated with epithelial ovarian cancer. Androgens may be a key therapeutic target in ovarian cancer, as anti-androgens have been shown to inhibit proliferation of ovarian cancer cells in some studies.

Analysis of intra-tumoural steroid metabolism suggests that androgen metabolism is altered and may promote formation of oestrogens, but it is not currently clear whether androgens have a direct impact on the tumour or whether they act solely as precursors to oestrogens. A better understanding of the local, intracrine activity of enzymes in affecting bioavailability of sex steroids in order to most effectively utilise combination therapies or new therapeutic agents such as SARMs is required. Further investigation will be required to understand the cell context-dependent impact of AR signalling and how AR-dependent signalling may crosstalk with other steroid receptors in the development and progression of disease.

\section{Declaration of interest}

The authors declare that there is no conflict of interest that could be perceived as prejudicing the impartiality of the review.

\section{Funding}

This work was supported by the Medical Research Council (grant number G1100356/1).

\section{Author contribution statement}

All authors contributed to the planning and writing of this review. P T K Saunders prepared the figure.

\section{References}

Abulafia O, Lee YC, Wagreich A, Economos K, Serur E \& Nacharaju VL 2009 Sulfatase activity in normal and neoplastic endometrium. Gynecologic and Obstetric Investigation 67 57-60. (doi:10.1159/000161571)

Ahrens-Fath I, Politz O, Geserick C \& Haendler B 2004 Androgen receptor function is modulated by the tissue-specific AR45 variant. FEBS Journal 272 74-84. (doi:10.1111/j.1432-1033.2004.04395.x)

Alexiadis M, Eriksson N, Jamieson S, Davis M, Drummond AE, Chu S, Clyne CD, Muscat GE \& Fuller PJ 2011 Nuclear receptor profiling of ovarian granulosa cell tumors. Hormones \& Cancer 2 157-169. (doi:10.1007/ s12672-011-0069-3)

Alhilli MM, Long HJ, Podratz KC \& Bakkum-Gamez JN 2012 Aromatase inhibitors in the treatment of recurrent ovarian granulosa cell tumors: brief report and review of the literature. Journal of Obstetrics and Gynaecology Research 38 340-344. (doi:10.1111/j.1447-0756.2011.01698.x)

Allen NE, Key TJ, Dossus L, Rinaldi S, Cust A, Lukanova A, Peeters PH, Onland-Moret NC, Lahmann PH, Berrino F et al. 2008 Endogenous sex hormones and endometrial cancer risk in women in the European
Prospective Investigation into Cancer and Nutrition (EPIC). EndocrineRelated Cancer 15 485-497. (doi:10.1677/ERC-07-0064)

Apparao KB, Lovely LP, Gui Y, Lininger RA \& Lessey BA 2002 Elevated endometrial androgen receptor expression in women with polycystic ovarian syndrome. Biology of Reproduction 66 297-304. (doi:10.1095/ biolreprod66.2.297)

Auersperg N 2013 Ovarian surface epithelium as a source of ovarian cancers: unwarranted speculation or evidence-based hypothesis? Gynecologic Oncology 130 246-251. (doi:10.1016/j.ygyno.2013.03.021)

Avances C, Georget V, Terouanne B, Orio F, Cussenot O, Mottet N, Costa P \& Sultan C 2001 Human prostatic cell line PNT1A, a useful tool for studying androgen receptor transcriptional activity and its differential subnuclear localization in the presence of androgens and antiandrogens. Molecular and Cellular Endocrinology 184 13-24. (doi:10.1016/ S0303-7207(01)00669-4)

Beesley J, Jordan SJ, Spurdle AB, Song H, Ramus SJ, Kjaer SK, Hogdall E, DiCioccio RA, McGuire V, Whittemore AS et al. 2007 Association between single-nucleotide polymorphisms in hormone metabolism and DNA repair genes and epithelial ovarian cancer: results from two Australian studies and an additional validation set. Cancer Epidemiology, Biomarkers \& Prevention 16 2557-2565. (doi:10.1158/1055-9965.EPI-07-0542)

Beral V, Bull D \& Reeves G 2005 Endometrial cancer and hormonereplacement therapy in the Million Women Study. Lancet 365 1543-1551. (doi:10.1016/S0140-6736(05)66455-0)

Beral V, Million Women Study C, Bull D, Green J \& Reeves G 2007 Ovarian cancer and hormone replacement therapy in the Million Women Study. Lancet 369 1703-1710. (doi:10.1016/S0140-6736(07)60534-0)

Bergman L, Beelen ML, Gallee MP, Hollema H, Benraadt J \& van Leeuwen FE 2000 Risk and prognosis of endometrial cancer after tamoxifen for breast cancer. Comprehensive Cancer Centres' ALERT Group. Assessment of Liver and Endometrial cancer Risk following Tamoxifen. Lancet 356 881-887. (doi:10.1016/S0140-6736(00)02677-5)

Bergstrom A, Pisani P, Tenet V, Wolk A \& Adami HO 2001 Overweight as an avoidable cause of cancer in Europe. International Journal of Cancer $\mathbf{9 1}$ 421-430. (doi:10.1002/1097-0215(200002)9999:9999<::AIDIJC1053 > 3.0.CO;2-T)

Berns EM \& Bowtell DD 2012 The changing view of high-grade serous ovarian cancer. Cancer Research 72 2701-2704. (doi:10.1158/00085472.CAN-11-3911)

Berstein LM, Tchernobrovkina AE, Gamajunova VB, Kovalevskij AJ, Vasilyev DA, Chepik OF, Turkevitch EA, Tsyrlina EV, Maximov SJ, Ashrafian LA et al. 2003 Tumor estrogen content and clinicomorphological and endocrine features of endometrial cancer Journal of Cancer Research and Clinical Oncology 129 245-249.

Birkeland E, Wik E, Mjos S, Hoivik EA, Trovik J, Werner HM, Kusonmano K, Petersen K, Raeder MB, Holst F et al. 2012 KRAS gene amplification and overexpression but not mutation associates with aggressive and metastatic endometrial cancer. British Journal of Cancer 107 1997-2004. (doi:10.1038/bjc.2012.477)

Borgfeldt C \& Andolf E 2004 Cancer risk after hospital discharge diagnosis of benign ovarian cysts and endometriosis. Acta Obstetricia et Gynecologica Scandinavica 83 395-400. (doi:10.1080/j.0001-6349.2004. 00305.x)

Bukulmez O, Hardy DB, Carr BR, Auchus RJ, Toloubeydokhti T, Word RA \& Mendelson CR 2008 Androstenedione up-regulation of endometrial aromatase expression via local conversion to estrogen: potential relevance to the pathogenesis of endometriosis. Journal of Clinical Endocrinology and Metabolism 93 3471-3477. (doi:10.1210/jc.2008-0248)

Butler MS, Ricciardelli C, Tilley WD \& Hickey TE 2013 Androgen receptor protein levels are significantly reduced in serous ovarian carcinomas compared with benign or borderline disease but are not altered by cancer stage or metastatic progression. Hormones \& Cancer 4 154-164. (doi:10.1007/s12672-013-0135-0)

Cao Y, Zhang S, Zou S \& Xia X 2013 The relationship between endogenous androgens and body fat distribution in early and late postmenopausal women. PLoS ONE 8 e58448. (doi:10.1371/journal.pone.0058448) 
Carneiro MM, Morsch DM, Camargos AF, Reis FM \& Spritzer PM 2008 Androgen receptor and $5 \alpha$-reductase are expressed in pelvic endometriosis. BJOG: an International Journal of Obstetrics and Gynaecology 115 113-117. (doi:10.1111/j.1471-0528.2007.01521.x)

Chamberlain NL, Driver ED \& Miesfeld RL 1994 The length and location of CAG trinucleotide repeats in the androgen receptor N-terminal domain affect transactivation function. Nucleic Acids Research 22 3181-3186. (doi:10.1093/nar/22.15.3181)

Chand AL, Herridge KA, Thompson EW \& Clyne CD 2010 The orphan nuclear receptor LRH-1 promotes breast cancer motility and invasion. Endocrine-Related Cancer 17 965-975. (doi:10.1677/ERC-10-0179)

Chand AL, Pathirage N, Lazarus K, Chu S, Drummond AE, Fuller PJ \& Clyne CD 2013 Liver receptor homologue-1 expression in ovarian epithelial and granulosa cell tumours. Steroids $\mathbf{7 8}$ 700-706. (doi:10.1016/j. steroids.2013.03.001)

Cheng KW, Lahad JP, Kuo WL, Lapuk A, Yamada K, Auersperg N, Liu J, Smith-McCune K, Lu KH, Fishman D et al. 2004 The RAB25 small GTPase determines aggressiveness of ovarian and breast cancers. Nature Medicine 10 1251-1256. (doi:10.1038/nm1125)

Claessens F, Denayer S, Van Tilborgh N, Kerkhofs S, Helsen C \& Haelens A 2008 Diverse roles of androgen receptor (AR) domains in AR-mediated signaling. Nuclear Receptor Signaling 6 e008. (doi:10.1621/nrs.06008)

Coffey K \& Robson CN 2012 Regulation of the androgen receptor by post-translational modifications. Journal of Endocrinology 215 221-237. (doi:10.1530/JOE-12-0238)

Collins F, MacPherson S, Brown P, Bombail V, Williams AR, Anderson RA, Jabbour HN \& Saunders PT 2009 Expression of oestrogen receptors, $E R \alpha$, ER $\beta$, and ER $\beta$ variants, in endometrial cancers and evidence that prostaglandin F may play a role in regulating expression of ER $\alpha$. BMC Cancer 9 330. (doi:10.1186/1471-2407-9-330)

Cottreau CM, Ness RB, Modugno F, Allen GO \& Goodman MT 2003 Endometriosis and its treatment with Danazol or lupron in relation to ovarian cancer. Clinical Cancer Research 9 5142-5144.

Dalton JT, Taylor RP, Mohler ML \& Steiner MS 2013 Selective androgen receptor modulators for the prevention and treatment of muscle wasting associated with cancer. Current Opinion in Supportive and Palliative Care 7 345-351. (doi:10.1097/SPC.0000000000000015)

Dart DA, Waxman J, Aboagye EO \& Bevan CL 2013 Visualising androgen receptor activity in male and female mice. PLOS ONE 8 e71694. (doi:10.1371/journal.pone.0071694)

Dobrzycka B, Terlikowski SJ, Mazurek A, Kowalczuk O, Niklinska W, Chyczewski L \& Kulikowski M 2009 Mutations of the KRAS oncogene in endometrial hyperplasia and carcinoma. Folia Histochemica et Cytobiologica 47 65-68. (doi:10.2478/v10042-009-0014-2)

Dossus L, Lukanova A, Rinaldi S, Allen N, Cust AE, Becker S, Tjonneland A, Hansen L, Overvad K, Chabbert-Buffet N et al. 2013 Hormonal, metabolic, and inflammatory profiles and endometrial cancer risk within the EPIC cohort - a factor analysis. American Journal of Epidemiology 177 787-799. (doi:10.1093/aje/kws309)

Dunning AM, Dowsett M, Healey CS, Tee L, Luben RN, Folkerd E, Novik KL, Kelemen L, Ogata S, Pharoah PD et al. 2004 Polymorphisms associated with circulating sex hormone levels in postmenopausal women. Journal of the National Cancer Institute 96 936-945. (doi:10.1093/jnci/djh167)

Earp MA, Kelemen LE, Magliocco AM, Swenerton KD, Chenevix-Trench G, Australian Cancer S, Australian Ovarian Cancer Study G, Lu Y, Hein A, Ekici $\mathrm{AB}$ et al. 2013 Genome-wide association study of subtype-specific epithelial ovarian cancer risk alleles using pooled DNA. Human Genetics.

Edmondson RJ, Monaghan JM \& Davies BR 2002 The human ovarian surface epithelium is an androgen responsive tissue. British Journal of Cancer 86 879-885. (doi:10.1038/sj.bjc.6600154)

Elattar A, Warburton KG, Mukhopadhyay A, Freer RM, Shaheen F, Cross P, Plummer ER, Robson CN \& Edmondson RJ 2012 Androgen receptor expression is a biological marker for androgen sensitivity in high grade serous epithelial ovarian cancer. Gynecologic Oncology 124 142-147. (doi:10.1016/j.ygyno.2011.09.004)
Emons G, Fleckenstein G, Hinney B, Huschmand A \& Heyl W 2000 Hormonal interactions in endometrial cancer. Endocrine-Related Cancer 7 227-242. (doi:10.1677/erc.0.0070227)

Fearnley EJ, Marquart L, Spurdle AB, Weinstein P \& Webb PM 2010 Polycystic ovary syndrome increases the risk of endometrial cancer in women aged less than 50 years: an Australian case-control study. Cancer Causes \& Control 21 2303-2308. (doi:10.1007/s10552-010-9658-7)

Ferlay J, Shin HR, Bray F, Forman D, Mathers C \& Parkin DM 2010 Estimates of worldwide burden of cancer in 2008: GLOBOCAN 2008. International Journal of Cancer 127 2893-2917. (doi:10.1002/ijc.25516)

Fournier MA \& Poirier D 2009 Estrogen formation in endometrial and cervix cancer cell lines: involvement of aromatase, steroid sulfatase and $17 \beta$ hydroxysteroid dehydrogenases (types 1, 5, 7 and 12). Molecular and Cellular Endocrinology 301 142-145. (doi:10.1016/j.mce.2008.08.027)

Fowler PA, Anderson RA, Saunders PT, Kinnell H, Mason JI, Evans DB, Bhattacharya S, Flannigan S, Franks S, Monteiro A et al. 2011 Development of steroid signaling pathways during primordial follicle formation in the human fetal ovary. Journal of Clinical Endocrinology and Metabolism 96 1754-1762. (doi:10.1210/jc.2010-2618)

Franks S 1995 Polycystic ovary syndrome. New England Journal of Medicine 333 853-861. (doi:10.1056/NEJM199509283331307)

Gao W \& Dalton JT 2007 Expanding the therapeutic use of androgens via selective androgen receptor modulators (SARMs). Drug Discovery Today 12 241-248. (doi:10.1016/j.drudis.2007.01.003)

Guzeloglu-Kayisli O, Kayisli UA, Al-Rejjal R, Zheng W, Luleci G \& Arici A 2003 Regulation of PTEN (phosphatase and tensin homolog deleted on chromosome 10) expression by estradiol and progesterone in human endometrium. Journal of Clinical Endocrinology and Metabolism $\mathbf{8 8}$ 5017-5026. (doi:10.1210/jc.2003-030414)

Hackenberg R \& Schulz K-D 1996 Androgen receptor mediated growth control of breast cancer and endometrial cancer modulated by antiandrogen- and androgen-like steroids. Journal of Steroid Biochemistry and Molecular Biology 56 113-117. (doi:10.1016/0960-0760(95)00228-6)

Hart R, Hickey M \& Franks S 2004 Definitions, prevalence and symptoms of polycystic ovaries and polycystic ovary syndrome. Best Practice \& Research. Clinical Obstetrics \& Gynaecology 18 671-683. (doi:10.1016/j. bpobgyn.2004.05.001)

Hausknecht V, Lopez de la Osa E \& Gurpide E 1982 In vitro metabolism of C19 steroids in human endometrium. Journal of Steroid Biochemistry $\mathbf{1 7}$ 621-629. (doi:10.1016/0022-4731(82)90563-5)

Hillier SG, Tetsuka M \& Fraser HM 1997 Location and developmental regulation of androgen receptor in primate ovary. Human Reproduction 12 107-111. (doi:10.1093/humrep/12.1.107)

Horie K, Takakura K, Fujiwara H, Suginami H, Liao S \& Mori T 1992 Immunohistochemical localization of androgen receptor in the human ovary throughout the menstrual cycle in relation to oestrogen and progesterone receptor expression. Human Reproduction 7 184-190.

Horne AW, King AE, Shaw E, McDonald SE, Williams AR, Saunders PT \& Critchley HO 2009 Attenuated sex steroid receptor expression in fallopian tube of women with ectopic pregnancy. Journal of Clinical Endocrinology and Metabolism 94 5146-5154. (doi:10.1210/jc. 2009-1476)

Hu YC, Wang PH, Yeh S, Wang RS, Xie C, Xu Q, Zhou X, Chao HT, Tsai MY \& Chang C 2004 Subfertility and defective folliculogenesis in female mice lacking androgen receptor. PNAS 101 11209-11214. (doi:10.1073/ pnas.0404372101)

Ito K, Suzuki T, Akahira J, Moriya T, Kaneko C, Utsunomiya H, Yaegashi N, Okamura K \& Sasano H 2002 Expression of androgen receptor and $5 \alpha$-reductases in the human normal endometrium and its disorders. International Journal of Cancer 99 652-657. (doi:10.1002/ijc.10394)

James SR, Cedeno CD, Sharma A, Zhang W, Mohler JL, Odunsi K, Wilson EM \& Karpf AR 2013 DNA methylation and nucleosome occupancy regulate the cancer germline antigen gene MAGEA11. Epigenetics 8 849-863. (doi:10.4161/epi.25500)

Jordan SJ, Green AC, Whiteman DC, Moore SP, Bain CJ, Gertig DM, Webb PM, Australian Cancer Study G \& Australian Ovarian Cancer Study G 2008 
Serous ovarian, fallopian tube and primary peritoneal cancers: a comparative epidemiological analysis. International Journal of Cancer 122 1598-1603. (doi:10.1002/ijc.23287)

Kandoth C, Schultz N, Cherniack AD, Akbani R, Liu Y, Shen H, Robertson AG, Pashtan I, Shen R, Benz CC et al. 2013 Integrated genomic characterization of endometrial carcinoma. Nature 497 67-73. (doi:10.1038/nature12113)

Kato J \& Seto T 1985 Correlation of androgen receptors with histological differentiation in human endometrial carcinomas. Acta Obstetricia et Gynecologica Scandinavica 64 209-212. (doi:10.3109/ 00016348509155114)

Kim J, Coffey DM, Creighton CJ, Yu Z, Hawkins SM \& Matzuk MM 2012 High-grade serous ovarian cancer arises from fallopian tube in a mouse model. PNAS 109 3921-3926. (doi:10.1073/pnas.1117135109)

Koivisto-Korander R, Butzow R, Koivisto AM \& Leminen A 2011 Immunohistochemical studies on uterine carcinosarcoma, leiomyosarcoma, and endometrial stromal sarcoma: expression and prognostic importance of ten different markers. Tumour Biology 32 451-459. (doi:10.1007/s13277-010-0138-1)

Korch C, Spillman MA, Jackson TA, Jacobsen BM, Murphy SK, Lessey BA, Jordan VC \& Bradford AP 2012 DNA profiling analysis of endometrial and ovarian cell lines reveals misidentification, redundancy and contamination. Gynecologic Oncology 127 241-248. (doi:10.1016/j. ygyno.2012.06.017)

Kuiper GGJM, Faber PW, van Rooij HCJ, van der Korput JAGM, Ris-Stalpers C, Klaassen P, Trapman J \& Brinkmann AO 1989 Structural organization of the human androgen receptor gene. Journal of Molecular Endocrinology 2 R1-R4. (doi:10.1677/jme.0.002R001)

Kumar R \& McEwan IJ 2012 Allosteric modulators of steroid hormone receptors: structural dynamics and gene regulation. Endocrine Reviews 33 271-299. (doi:10.1210/er.2011-1033)

Kurman RJ \& Shih Ie M 2011 Molecular pathogenesis and extraovarian origin of epithelial ovarian cancer - shifting the paradigm. Human Pathology 42 918-931. (doi:10.1016/j.humpath.2011.03.003)

Lanzino M, Sisci D, Morelli C, Garofalo C, Catalano S, Casaburi I, Capparelli C, Giordano C, Giordano F, Maggiolini M et al. 2010 Inhibition of cyclin D1 expression by androgen receptor in breast cancer cells identification of a novel androgen response element. Nucleic Acids Research 38 5351-5365. (doi:10.1093/nar/gkq278)

Lepine J, Audet-Walsh E, Gregoire J, Tetu B, Plante M, Menard V, Ayotte P, Brisson J, Caron P, Villeneuve L et al. 2010 Circulating estrogens in endometrial cancer cases and their relationship with tissular expression of key estrogen biosynthesis and metabolic pathways. Journal of Clinical Endocrinology and Metabolism 95 2689-2698. (doi:10.1210/jc.2010-2648)

Lewin SN 2011 Revised FIGO staging system for endometrial cancer. Clinical Obstetrics and Gynecology 54 215-218. (doi:10.1097/GRF. Ob013e3182185baa)

Li AJ, Baldwin RL \& Karlan BY 2003 Short androgen receptor allele length is a poor prognostic factor in epithelial ovarian carcinoma. Clinical Cancer Research 9 3667-3673.

Li AJ, Lerner DL, Gapuzan ME \& Karlan BY 2005 AIB1 polymorphisms predict aggressive ovarian cancer phenotype. Cancer Epidemiology, Biomarkers \& Prevention 14 2919-2922. (doi:10.1158/1055-9965.EPI05-0540)

Liang S, Mu K, Wang Y, Zhou Z, Zhang J, Sheng Y \& Zhang T 2013 CyclinD1, a prominent prognostic marker for endometrial diseases. Diagnostic Pathology 8 138. (doi:10.1186/1746-1596-8-138)

Ligr M, Patwa RR, Daniels G, Pan L, Wu X, Li Y, Tian L, Wang Z, Xu R, Wu J et al. 2011 Expression and function of androgen receptor coactivator p44/Mep50/WDR77 in ovarian cancer. PLoS ONE 6 e26250. (doi:10.1371/journal.pone.0026250)

Lin HY, Sun M, Lin C, Tang HY, London D, Shih A, Davis FB \& Davis PJ $2009 a$ Androgen-induced human breast cancer cell proliferation is mediated by discrete mechanisms in estrogen receptor- $\alpha$-positive and -negative breast cancer cells. Journal of Steroid Biochemistry and Molecular Biology 113 182-188. (doi:10.1016/j.jsbmb.2008.12.010)
Lin SL, Yan LY, Liang XW, Wang ZB, Wang ZY, Qiao J, Schatten H \& Sun QY $2009 b$ A novel variant of ER- $\alpha$, ER- $\alpha 36$ mediates testosterone-stimulated ERK and Akt activation in endometrial cancer Hec1A cells. Reproductive Biology and Endocrinology 7 102. (doi:10.1186/1477-7827-7-102)

Lovely LP, Appa Rao KB, Gui Y \& Lessey BA 2000 Characterization of androgen receptors in a well-differentiated endometrial adenocarcinoma cell line (Ishikawa). Journal of Steroid Biochemistry and Molecular Biology 74 235-241. (doi:10.1016/S0960-0760(00)00127-8)

Lubahn DB, Joseph DR, Sullivan PM, Willard HF, French FS \& Wilson EM 1988 Cloning of human androgen receptor complementary DNA and localization to the X chromosome. Science 240 327-330. (doi:10.1126/ science.3353727)

Lundin E, Wirgin I, Lukanova A, Afanasyeva Y, Krogh V, Axelsson T, Hemminki K, Clendenen TV, Arslan AA, Ohlson N et al. 2012 Selected polymorphisms in sex hormone-related genes, circulating sex hormones and risk of endometrial cancer. Cancer Epidemiology 36 445-452. (doi:10.1016/j.canep.2012.04.006)

Lyu S, Yu Q, Ying G, Wang S, Wang Y, Zhang J \& Niu Y 2014 Androgen receptor decreases CMYC and KRAS expression by upregulating let-7a expression in $\mathrm{ER}-, \mathrm{PR}-, \mathrm{AR}+$ breast cancer. International Journal of Oncology 44 229-237. (doi:10.3892/ijo.2013.2151)

Mardanian F \& Heidari N 2011 Diagnostic value of prostate-specific antigen in women with polycystic ovary syndrome. Journal of Research in Medical Sciences 16 999-1005.

Marshall E, Lowrey J, MacPherson S, Maybin JA, Collins F, Critchley HO \& Saunders PT 2011 In silico analysis identifies a novel role for androgens in the regulation of human endometrial apoptosis. Journal of Clinical Endocrinology and Metabolism 96 E1746-E1755. (doi:10.1210/jc. 2011-0272)

McEwan IJ, McGuinness D, Hay CW, Millar RP, Saunders PT \& Fraser HM 2010 Identification of androgen receptor phosphorylation in the primate ovary in vivo. Reproduction 140 93-104. (doi:10.1530/REP-100140)

McGrath M, Lee IM, Hankinson SE, Kraft P, Hunter DJ, Buring J \& De Vivo I 2006 Androgen receptor polymorphisms and endometrial cancer risk. International Journal of Cancer 118 1261-1268. (doi:10.1002/ijc.21436)

Mendez C, Morales-Vasquez F, Perez-Montiel D, Gomora MJ, EspinolaZetina C, Hernandez-Martinez A, Lopez-Basave H \& Pedernera E 2013 Estrogen and androgen receptor expression in surface epithelium and inclusion cyst in the ovary of premenopausal and postmenopausal women. Journal of Ovarian Research 6 85. (doi:10.1186/1757-2215-6-85) (doi:10.1186/1757-2215-6-85)

Mertens HJ, Heineman MJ, Theunissen PH, de Jong FH \& Evers JL 2001 Androgen, estrogen and progesterone receptor expression in the human uterus during the menstrual cycle. European Journal of Obstetrics, Gynecology, and Reproductive Biology 98 58-65. (doi:10.1016/S03012115(00)00554-6)

Mhawech-Fauceglia P, Smiraglia DJ, Bshara W, Andrews C, Schwaller J, South S, Higgs D, Lele S, Herrmann F \& Odunsi K 2008 Prostate-specific membrane antigen expression is a potential prognostic marker in endometrial adenocarcinoma. Cancer Epidemiology, Biomarkers \& Prevention 17 571-577. (doi:10.1158/1055-9965.EPI-07-0511)

Modugno F, Laskey R, Smith AL, Andersen CL, Haluska P \& Oesterreich S 2012 Hormone response in ovarian cancer: time to reconsider as a clinical target? Endocrine-Related Cancer 19 R255-R279. (doi:10.1530/ ERC-12-0175)

Montgomery BT, Young CY, Bilhartz DL, Andrews PE, Prescott JL, Thompson NF \& Tindall DJ 1992 Hormonal regulation of prostate-specific antigen (PSA) glycoprotein in the human prostatic adenocarcinoma cell line, LNCaP. Prostate 21 63-73. (doi:10.1002/ pros.2990210107)

Moreno-Bueno G, Rodriguez-Perales S, Sanchez-Estevez C, Hardisson D, Sarrio D, Prat J, Cigudosa JC, Matias-Guiu X \& Palacios J 2003 Cyclin D1 gene (CCND1) mutations in endometrial cancer. Oncogene 22 6115-6118. (doi:10.1038/sj.onc.1206868) 
Mutter GL, Lin MC, Fitzgerald JT, Kum JB, Baak JP, Lees JA, Weng LP \& Eng C 2000 $a$ Altered PTEN expression as a diagnostic marker for the earliest endometrial precancers. Journal of the National Cancer Institute 92 924-930. (doi:10.1093/jnci/92.11.924)

Mutter GL, Lin MC, Fitzgerald JT, Kum JB \& Eng C 2000b Changes in endometrial PTEN expression throughout the human menstrual cycle. Journal of Clinical Endocrinology and Metabolism 85 2334-2338. (doi:10.1210/jcem.85.6.6652)

Need EF, Selth LA, Harris TJ, Birrell SN, Tilley WD \& Buchanan G 2012 Research resource: interplay between the genomic and transcriptional networks of androgen receptor and estrogen receptor $\alpha$ in luminal breast cancer cells. Molecular Endocrinology 26 1941-1952. (doi:10.1210/ me.2011-1314)

Nishida M, Kasahara K, Oki A, Satoh T, Arai Y \& Kubo T 1996 Establishment of eighteen clones of Ishikawa cells. Human Cell 9 109-116.

Niwa K, Hashimoto M, Morishita S, Yokoyama Y, Lian ZL, Tagami K, Mori H \& Tamaya T 2000 Preventive effects of Danazol on endometrial carcinogenesis in mice. Cancer Letters 158 133-139. (doi:10.1016/ S0304-3835(00)00497-3)

Ochnik AM, Moore NL, Jankovic-Karasoulos T, Bianco-Miotto T, Ryan NK, Thomas MR, Birrell SN, Butler LM, Tilley WD \& Hickey TE 2014 Antiandrogenic actions of medroxyprogesterone acetate on epithelial cells within normal human breast tissues cultured ex vivo. Menopause 21 79-88. (doi:10.1097/GME.0b013e3182936ef4)

Olsen CM, Green AC, Nagle CM, Jordan SJ, Whiteman DC, Bain CJ, Webb PM, Australian Cancer Study G \& the Australian Ovarian Cancer Study G 2008 Epithelial ovarian cancer: testing the 'androgens hypothesis'. Endocrine-Related Cancer 15 1061-1068. (doi:10.1677/ERC-08-0075)

Olson SH, Bandera EV \& Orlow I 2007 Variants in estrogen biosynthesis genes, sex steroid hormone levels, and endometrial cancer: a HuGE review. American Journal of Epidemiology 165 235-245. (doi:10.1093/aje/ kwk015)

Paik DY, Janzen DM, Schafenacker AM, Velasco VS, Shung MS, Cheng D, Huang J, Witte ON \& Memarzadeh S 2012 Stem-like epithelial cells are concentrated in the distal end of the fallopian tube: a site for injury and serous cancer initiation. Stem Cells 30 2487-2497. (doi:10.1002/stem.1207)

Pearce CL, Templeman C, Rossing MA, Lee A, Near AM, Webb PM, Nagle CM, Doherty JA, Cushing-Haugen KL, Wicklund KG et al. 2012 Association between endometriosis and risk of histological subtypes of ovarian cancer: a pooled analysis of case-control studies. Lancet Oncology $\mathbf{1 3}$ 385-394. (doi:10.1016/S1470-2045(11)70404-1)

Piek JM, van Diest PJ, Zweemer RP, Jansen JW, Poort-Keesom RJ, Menko FH, Gille JJ, Jongsma AP, Pals G, Kenemans P et al. 2001 Dysplastic changes in prophylactically removed Fallopian tubes of women predisposed to developing ovarian cancer. Journal of Pathology 195 451-456. (doi:10.1002/path.1000)

Poukka H, Karvonen U, Janne OA \& Palvimo JJ 2000 Covalent modification of the androgen receptor by small ubiquitin-like modifier 1 (SUMO-1). PNAS 97 14145-14150. (doi:10.1073/pnas.97.26.14145)

Prat J 2012 New insights into ovarian cancer pathology. Annals of Oncology 23 (Suppl 10) x111-x117. (doi:10.1093/annonc/mds300)

Prat J 2013 Staging classification for cancer of the ovary, fallopian tube, and peritoneum. International Journal of Gynaecology and Obstetrics 124 1-5. (doi:10.1016/j.ijgo.2013.10.001)

Purdie DM \& Green AC 2001 Epidemiology of endometrial cancer. Best Practice \& Research. Clinical Obstetrics \& Gynaecology 15 341-354. (doi:10.1053/beog.2000.0180)

Rabban JT \& Bell DA 2005 Current issues in the pathology of ovarian cancer. Journal of Reproductive Medicine 50 467-474.

Ramus SJ, Vierkant RA, Johnatty SE, Pike MC, Van Den Berg DJ, Wu AH, Pearce CL, Menon U, Gentry-Maharaj A, Gayther SA et al. 2008 Consortium analysis of 7 candidate SNPs for ovarian cancer. International Journal of Cancer 123 380-388. (doi:10.1002/ijc.23448)

Reeves GK, Pirie K, Beral V, Green J, Spencer E, Bull D \& Million Women Study C 2007 Cancer incidence and mortality in relation to body mass index in the Million Women Study: cohort study. BMJ 3351134 (doi:10.1136/bmj.39367.495995.AE)

Ren Q, Zhang L, Ruoff R, Ha S, Wang J, Jain S, Reuter V, Gerald W, Giri DD, Melamed J et al. 2013 Expression of androgen receptor and its phosphorylated forms in breast cancer progression. Cancer 119 2532-2540. (doi:10.1002/cncr.28092)

Rice MS, Murphy MA, Vitonis AF, Cramer DW, Titus LJ, Tworoger SS \& Terry KL 2013 Tubal ligation, hysterectomy and epithelial ovarian cancer in the New England Case-Control Study. International Journal of Cancer 133 2415-2421. (doi:10.1002/ijc.28249)

Rizner TL 2013 Estrogen biosynthesis, phase I and phase II metabolism, and action in endometrial cancer. Molecular and Cellular Endocrinology $\mathbf{3 8 1}$ 124-139. (doi:10.1016/j.mce.2013.07.026)

Rizner TL, Smuc T, Rupreht R, Sinkovec J \& Penning TM 2006 AKR1C1 and AKR1C3 may determine progesterone and estrogen ratios in endometrial cancer. Molecular and Cellular Endocrinology 248 126-135. (doi:10.1016/j.mce.2005.10.009)

Rodríguez G, Bilbao C, Ramírez R, Falcón O, León L, Chirino R, Díaz BP, Rivero JF, Perucho M, Díaz-Chico BN et al. 2006 Alleles with short CAG and GGN repeats in the androgen receptor gene are associated with benign endometrial cancer. International Journal of Cancer $\mathbf{1 1 8}$ 1420-1425. (doi:10.1002/ijc.21516)

Rose LI, Reddy VV \& Biondi R 1978 Reduction of testosterone to $5 \alpha$-dihydrotestosterone by human and rat uterine tissues. Journal of Clinical Endocrinology and Metabolism 46 766-769. (doi:10.1210/ jcem-46-5-766)

Rytinki M, Kaikkonen S, Sutinen P, Paakinaho V, Rahkama V \& Palvimo JJ 2012 Dynamic SUMOylation is linked to the activity cycles of androgen receptor in the cell nucleus. Molecular and Cellular Biology 32 4195-4205. (doi:10.1128/MCB.00753-12)

Saloniemi T, Lamminen T, Huhtinen K, Welsh M, Saunders P, Kujari H \& Poutanen M 2007 Activation of androgens by hydroxysteroid (17 $\beta$ ) dehydrogenase 1 in vivo as a cause of prenatal masculinization and ovarian benign serous cystadenomas. Molecular Endocrinology 21 2627-2636. (doi:10.1210/me.2007-0144)

Samojlik E, Kirschner MA, Silber D, Schneider G \& Ertel NH 1984 Elevated production and metabolic clearance rates of androgens in morbidly obese women. Journal of Clinical Endocrinology and Metabolism 59 949-954. (doi:10.1210/jcem-59-5-949)

Sasaki M, Oh BR, Dharia A, Fujimoto S \& Dahiya R 2000 Inactivation of the human androgen receptor gene is associated with CpG hypermethylation in uterine endometrial cancer. Molecular Carcinogenesis 29 59-66. (doi:10.1002/1098-2744(200010)29:2<59::AID-MC2>3.0.CO;2-6)

Saunders PT, Millar MR, Williams K, Macpherson S, Harkiss D, Anderson RA, Orr B, Groome NP, Scobie G \& Fraser HM 2000 Differential expression of estrogen receptor- $\alpha$ and $-\beta$ and androgen receptor in the ovaries of marmosets and humans. Biology of Reproduction 63 1098-1105 (doi:10.1095/biolreprod63.4.1098)

Schouten LJ, Rivera C, Hunter DJ, Spiegelman D, Adami HO, Arslan A, Beeson WL, van den Brandt PA, Buring JE, Folsom AR et al. 2008 Height, body mass index, and ovarian cancer: a pooled analysis of 12 cohort studies. Cancer Epidemiology, Biomarkers \& Prevention 17 902-912. (doi:10.1158/1055-9965.EPI-07-2524)

Schumer ST \& Cannistra SA 2003 Granulosa cell tumor of the ovary. Journal of Clinical Oncology 21 1180-1189. (doi:10.1200/JCO.2003.10.019)

Setiawan VW, Yang HP, Pike MC, McCann SE, Yu H, Xiang YB, Wolk A, Wentzensen N, Weiss NS, Webb PM et al. 2013 Type I and II endometrial cancers: have they different risk factors? Journal of Clinical Oncology 31 2607-2618. (doi:10.1200/JCO.2012.48.2596)

Sheach LA, Adeney EM, Kucukmetin A, Wilkinson SJ, Fisher AD, Elattar A, Robson CN \& Edmondson RJ 2009 Androgen-related expression of G-proteins in ovarian cancer. British Journal of Cancer 101 498-503. (doi:10.1038/sj.bjc.6605153)

Sieh W, Kobel M, Longacre TA, Bowtell DD, deFazio A, Goodman MT, Hogdall E, Deen S, Wentzensen N, Moysich KB et al. 2013a Hormonereceptor expression and ovarian cancer survival: an Ovarian Tumor 
Tissue Analysis consortium study. Lancet Oncology 14 853-862. (doi:10. 1016/S1470-2045(13)70253-5)

Sieh W, Salvador S, McGuire V, Weber RP, Terry KL, Rossing MA, Risch H, Wu AH, Webb PM, Moysich K et al. 2013b Tubal ligation and risk of ovarian cancer subtypes: a pooled analysis of case-control studies. International Journal of Epidemiology 42 579-589. (doi:10.1093/ije/dyt042)

Simpson ER, Zhao Y, Agarwal VR, Michael MD, Bulun SE, Hinshelwood MM, Graham-Lorence S, Sun T, Fisher CR, Qin K et al. 1997 Aromatase expression in health and disease. Recent Progress in Hormone Research 52 185-213 (discussion 213-214).

Sinreih M, Hevir N \& Rizner TL 2013 Altered expression of genes involved in progesterone biosynthesis, metabolism and action in endometrial cancer. Chemico-Biological Interactions 202 210-217. (doi:10.1016/j.cbi. 2012.11.012)

Smuc T, Rupreht R, Sinkovec J, Adamski J \& Rizner TL 2006 Expression analysis of estrogen-metabolizing enzymes in human endometrial cancer. Molecular and Cellular Endocrinology 248 114-117. (doi:10.1016/ j.mce.2005.10.013)

Song K, Wang H, Krebs TL, Wang B, Kelley TJ \& Danielpour D 2010 DHT selectively reverses Smad3-mediated/TGF- $\beta$-induced responses through transcriptional down-regulation of Smad3 in prostate epithelial cells. Molecular Endocrinology 24 2019-2029. (doi:10.1210/me.2010-0165)

Spada ARL, Wilson EM \& Lubahn DB 1991 Androgen receptor gene mutations in X-linked spinal and bulbar muscular atrophy. Nature 352 77-79. (doi:10.1038/352077a0)

Syed V, Ulinski G, Mok SC, Yiu GK \& Ho SM 2001 Expression of gonadotropin receptor and growth responses to key reproductive hormones in normal and malignant human ovarian surface epithelial cells. Cancer Research 61 6768-6776.

Tamm-Rosenstein K, Simm J, Suhorutshenko M, Salumets A \& Metsis M 2013 Changes in the transcriptome of the human endometrial Ishikawa cancer cell line induced by estrogen, progesterone, tamoxifen, and mifepristone (RU486) as detected by RNA-sequencing. PLOS ONE $\mathbf{8}$ e68907. (doi:10.1371/journal.pone.0068907)

Tan DS, Iravani M, McCluggage WG, Lambros MB, Milanezi F, Mackay A, Gourley C, Geyer FC, Vatcheva R, Millar J et al. 2011 Genomic analysis reveals the molecular heterogeneity of ovarian clear cell carcinomas. Clinical Cancer Research 17 1521-1534. (doi:10.1158/1078-0432.CCR10-1688)

Tan TZ, Miow QH, Huang RY, Wong MK, Ye J, Lau JA, Wu MC, Bin Abdul Hadi LH, Soong R, Choolani M et al. 2013 Functional genomics identifies five distinct molecular subtypes with clinical relevance and pathways for growth control in epithelial ovarian cancer. EMBO Molecular Medicine 5 983-998. (doi:10.1002/emmm.201201823)

Van Nieuwenhuysen E, Lambrechts S, Lambrechts D, Leunen K, Amant F \& Vergote I 2013 Genetic changes in nonepithelial ovarian cancer. Expert Review of Anticancer Therapy 13 871-882. (doi:10.1586/14737140.2013. 811174)

Vera L, Accornero M, Mora M, Valenzano-Menada M, Minuto F \& Giusti M 2013 Increasing hirsutism due to a granulosa-cell tumor in a woman with polycystic ovary syndrome: case report and review of the literature. Gynecological Endocrinology 29 273-277. (doi:10.3109/ 09513590.2012.743012)

Voet A, Helsen C, Zhang KY \& Claessens F 2013 The discovery of novel human androgen receptor antagonist chemotypes using a combined pharmacophore screening procedure. ChemMedChem 8 644-651. (doi:10.1002/cmdc.201200549)

Walters KA, Allan CM, Jimenez M, Lim PR, Davey RA, Zajac JD, Illingworth P \& Handelsman DJ 2007 Female mice haploinsufficient for an inactivated androgen receptor (AR) exhibit age-dependent defects that resemble the AR null phenotype of dysfunctional late follicle development, ovulation, and fertility. Endocrinology 148 3674-3684. (doi:10.1210/en.2007-0248)

Walters KA, McTavish KJ, Seneviratne MG, Jimenez M, McMahon AC, Allan CM, Salamonsen LA \& Handelsman DJ 2009 Subfertile female androgen receptor knockout mice exhibit defects in neuroendocrine signaling, intraovarian function, and uterine development but not uterine function. Endocrinology 150 3274-3282. (doi:10.1210/en.2008-1750)

Walters KA, Middleton LJ, Joseph SR, Hazra R, Jimenez M, Simanainen U, Allan CM \& Handelsman DJ 2012 Targeted loss of androgen receptor signaling in murine granulosa cells of preantral and antral follicles causes female subfertility. Biology of Reproduction 87 151. (doi:10.1095/ biolreprod.112.102012)

Wang H, Song K, Sponseller TL \& Danielpour D 2005 Novel function of androgen receptor-associated protein $55 / \mathrm{Hic}-5$ as a negative regulator of Smad3 signaling. Journal of Biological Chemistry 280 5154-5162. (doi:10.1074/jbc.M411575200)

Wang Y, Romigh T, He X, Tan MH, Orloff MS, Silverman RH, Heston WD \& Eng C 2011 Differential regulation of PTEN expression by androgen receptor in prostate and breast cancers. Oncogene $304327-4338$. (doi:10.1038/onc.2011.144)

Wu Y, Baumgarten SC, Zhou P \& Stocco C 2013 Testosterone-dependent interaction between androgen receptor and aryl hydrocarbon receptor induces liver receptor homolog 1 expression in rat granulosa cells. Molecular and Cellular Biology 33 2817-2828. (doi:10.1128/МСB.00011-13)

Yamamoto T, Kitawaki J, Urabe M, Honjo H, Tamura T, Noguchi T, Okada H, Sasaki H, Tada A, Terashima Y et al. 1993 Estrogen productivity of endometrium and endometrial cancer tissue; influence of aromatase on proliferation of endometrial cancer cells. Journal of Steroid Biochemistry and Molecular Biology 44 463-468. (doi:10.1016/0960-0760(93)90251-Q)

Yang HP, Garcia-Closas M, Lacey JV, Brinton L, Lissowska J, Peplonska B, Chanock S \& Gaudet MM 2009 Genetic variation in the androgen receptor gene and endometrial cancer risk. Cancer Epidemiology, Biomarkers \& Prevention 18 585-589. (doi:10.1158/1055-9965.EPI-08-0677)

Yang HP, Gonzalez Bosquet J, Li Q, Platz EA, Brinton LA, Sherman ME, Lacey JV Jr, Gaudet MM, Burdette LA, Figueroa JD et al. 2010 Common genetic variation in the sex hormone metabolic pathway and endometrial cancer risk: pathway-based evaluation of candidate genes. Carcinogenesis 31 827-833. (doi:10.1093/carcin/bgp328)

Zang H, Sahlin L, Masironi B, Eriksson E \& Linden Hirschberg A 2007 Effects of testosterone treatment on endometrial proliferation in postmenopausal women. Journal of Clinical Endocrinology and Metabolism 92 2169-2175. (doi:10.1210/jc.2006-2171)

Zhao H, Dupont J, Yakar S, Karas M \& LeRoith D 2004 PTEN inhibits cell proliferation and induces apoptosis by downregulating cell surface IGF-IR expression in prostate cancer cells. Oncogene 23 786-794. (doi:10.1038/sj.onc.1207162)

Zhu ML \& Kyprianou N 2010 Role of androgens and the androgen receptor in epithelial-mesenchymal transition and invasion of prostate cancer cells. FASEB Journal 24 769-777. (doi:10.1096/fj.09-136994)

Received in final form 17 February 2014

Accepted 24 February 2014

Made available online as an Accepted Preprint

28 February 2014 http://erc.endocrinology-journals.org DOI: 10.1530/ERC-13-0551
(C) 2014 Society for Endocrinology Printed in Great Britain
Published by Bioscientifica Ltd 